Received: 11 Februari 2019

Revised: 5 Maret 2019

Accepted: 18 Maret 2019

Published: 28 Juni 2019

\title{
PENGELOMPOKAN PENGGUNA INTERNET DENGAN METODE K-MEANS CLUSTERING
}

\author{
Disi Amalia P. ${ }^{1, \text { a) }}$, Bagus Sumargo ${ }^{2, \text { b) }}$ \\ ${ }^{1}$ Program Studi Matematika, Fakultas Matematika dan Ilmu Pengetahuan Alam, Universitas Negeri Jakarta \\ ${ }^{2}$ Program Studi Statistika, Fakultas Matematika dan Ilmu Pengetahuan Alam, Universitas Negeri Jakarta \\ Email: ${ }^{\text {a) }}$ disipramudita1997@gmail.com, ${ }^{\text {b) }}$ bagussumargo63@gmail.com
}

\begin{abstract}
Digital disparities still exists between internet users in urban and rural areas of Indonesia, therefore it is necessary to classify provinces based on the percentage of internet users. The grouping method used is the K-Means Clustering method. The purpose of this study is to group provinces based on internet users into three clusters to find out which provinces have good infrastructure so that they can support internet use. The average percentage of internet users in each cluster 1, cluster 2 , and cluster 3 is $40.91 \% ; 72.27 \%$; and $57.60 \%$. There needs to be an equal distribution of infrastructure that supports internet use in Indonesian society.
\end{abstract}

Keywords: K-Means Clustering, Clustering, Internet users.

\begin{abstract}
Abstrak
Kesenjangan digital masih terjadi antara pengguna internet di wilayah perkotaan dan pedesaan Indonesia, oleh karena itu, perlu dilakukan upaya untuk mengelompokan provinsi berdasarkan persentase pengguna internet. Metode pengelompokan yang digunakan adalah metode K-Means Clustering. Tujuan dari studi ini adalah mengelompokan provinsi berdasarkan pengguna internet menjadi tiga cluster untuk mengetahui provinsi-provinsi mana yang memiliki infrastruktur yang baik, sehingga dapat mendukung penggunaan internet. Rata-rata persentase jumlah pengguna internet masing-masing cluster 1 , cluster 2 , dan cluster 3 adalah 40,91\%; 72,27\%; dan 57,60\%. Perlu adanya pemerataan infrastruktur yang mendukung penggunaan internet pada masyarakat Indonesia.
\end{abstract}

Kata-kata kunci K-Means Clustering, 3 Cluster, Pengguna Internet.

\section{PENDAHULUAN}

Pada era globalisasi saat ini, ilmu pengetahuan dan teknologi berkembang dengan begitu pesat. Salah satu akibat dari berkembangnya teknologi yang semakin canggih adalah meluasnya penggunaan internet. Pengguna internet di Indonesia semakin meningkat setiap tahunnya. Walaupun pengguna 
internet di Indonesia semakin meningkat, namun masih ada kesenjangan digital yang kuat antara anak dan remaja yang tinggal di wilayah perkotaan (lebih sejahtera) di Indonesia, dengan mereka yang tinggal di wilayah pedesaan (dan kurang sejahtera). Di daerah perkotaan, hanya 13 persen dari anak dan remaja yang tidak menggunakan internet, sementara di daerah pedesaan ada 87 persen anak dan remaja yang tidak memakai internet (Panji, 2014).

Untuk itu perlu mengelompokkan provinsi berdasarkan persentase siswa umur 5-24 tahun yang mengakses internet selama 3 bulan terakhir menurut jenjang pendidikan. Pengelompokan dilakukan untuk mengetahui provinsi-provinsi mana yang memiliki infrastruktur baik untuk mendukung penggunaan internet dan provinsi-provinsi mana yang perlu dilakukan perbaikan infrastruktur untuk mendukung penggunaan internet pada masyarakat. Salah satu metode yang dapat digunakan untuk melakukan proses pengelompokan adalah analisis cluster.

Pada dasarnya, analisis cluster adalah metode analisis data yang termasuk dalam analisis statistik multivariat metode interdependensi, karena itu tujuan analisis cluster tidak untuk menghubungkan ataupun membedakan antar beberapa variabel. Analisis cluster terbagi menjadi dua metode yaitu, metode hierarki dan metode non-hierarki. Pada penelitian ini akan digunakan metode $k$-means clustering yang termasuk dalam metode non-hierarki untuk menganalisis data persentase siswa umur 5-24 tahun yang mengakses internet selama 3 bulan terakhir menurut jenjang pendidikan di Indonesia. $K$-Means clustering mempunyai kemampuan mengelompokkan data dalam jumlah yang cukup besar dengan waktu komputasi yang relatif cepat dan efisien (Arai, 2007).

Mengacu pada hal di atas maka akan dilakukan pengelompokan provinsi berdasarkan Persentase Pengguna Internet menurut Jenjang Pendidikan dengan Metode K-Means Clustering dan bantuan aplikasi software IBM SPSS 25.

\section{METODE}

\section{Analisis Cluster}

Analisis multivariat adalah suatu metode statistika yang digunakan untuk mengolah atau menganalisis data yang memiliki banyak variabel. Tujuan analisis multivariat adalah untuk mencari pengaruh variabel-variabel tersebut terhadap suatu objek. Analisis multivariat terbagi menjadi 2 kategori yaitu metode dependensi dan metode interdependensi.

Analisis cluster merupakan salah satu analisis multivariat yang mengelompokan objek-objek atau data ke dalam beberapa kelompok dimana setiap objek dalam satu kelompok memiliki karakteristik yang sama. Suatu cluster dikatakan cluster yang baik jika memiliki ciri-ciri sebagai berikut:

1. Homogenitas internal (within-cluster), yaitu memiliki tingkat kesamaan yang tinggi antar anggota dalam satu cluster.

2. Heterogenitas eksternal (between-cluster), yaitu memiliki tingkat perbedaan yang tinggi antar cluster yang satu dengan cluster yang lain.

Adapun langkah-langkah untuk mengelompokan data dengan menggunakan analisis cluster adalah sebagai berikut.

\section{Melakukan Proses Standardisasi Data}

Dalam analisis cluster terkadang data yang didapat memiliki satuan yang beranekaragam. Jika terdapat satuan yang berbeda dalam data, maka perlu dilakukan proses standardisasi data dengan mengubahnya ke bentuk z-score. Standardisasi data dapat dilakukan dengan rumus berikut:

$$
z=\frac{x-\bar{X}}{\sigma}
$$

\section{Keterangan}

$z \quad$ : Nilai data setelah di standardisasi

$x \quad$ : Nilai data asli 
$\begin{array}{ll}\bar{X} & : \text { Nilai rata - rata keseluruhan keseluruhan } \\ \sigma & : \text { Simpangan baku }\end{array}$

Menentukan Ukuran Kemiripan antar Data/Objek

Dalam analisis cluster diperlukan beberapa ukuran untuk mengetahui seberapa mirip objek-objek yang akan dikelompokan ke dalam cluster yang sama. Terdapat tiga metode yang digunakan dalam mengukur kemiripan / kesamaan antar objek yaitu ukuran korelasi, asosiasi dan jarak. Dalam ukuran jarak, jarak yang kecil menunjukan tingginya tingkat kesamaan antar objek. Dalam mengukur jarak antara dua objek, dapat digunakan ukuran jarak Euclidean. Berikut merupakan rumus mencari jarak Euclidean:

$$
d_{i j}=\sqrt{\sum_{k=1}^{p}\left(x_{i k}-x_{j k}\right)^{2}}
$$

Keterangan

$$
\begin{array}{ll}
d_{i j} & : \text { Jarak antara objek ke-i dengan objek ke-j } \\
i & : 1,2,3, \ldots, \mathrm{n} \\
j & : 1,2,3, \ldots, \mathrm{n} \\
k & : 1,2,3, \ldots, \mathrm{p} \\
n & : \text { Banyaknya objek } \\
p & : \text { Banyaknya peubah atau variabel } \\
x_{i k} & : \text { Nilai/data objek ke-i variabel ke-k } \\
x_{j k} & : \text { Nilai/data objek ke-j variabel ke-k }
\end{array}
$$

\section{Melakukan Proses Clustering dengan Metode yang Dipilih}

Terdapat dua metode pengelompokan yang dapat digunakan dalam analisis cluster, yaitu sebagai berikut.

1. Metode Hirarki

Pengelompokan dengan metode hirarki dimulai dengan mengelompokan dua atau lebih objek yang mempunyai kesamaan paling dekat. Kemudian proses pengelompokan diteruskan ke objek lainnya yang mempunyai kedekatan kedua. Demikian seterusnya sampai cluster membentuk tingkatan (hirarki). Hasil pengelompokan metode hirarki membentuk sebuah dendogram yang digunakan untuk membantu menjelaskan proses hirarki tersebut. Metode hirarki terbagi menjadi dua, yaitu sebagai berikut.

a. Metode Agglomerative (Penggabungan)

Pengelompokan metode Agglomerative dimulai dengan menganggap setiap objek sebagai sebuah cluster. Kemudian dua objek dengan jarak terdekat digabungakan menjadi satu cluster baru. Selanjutnya objek ketiga akan bergabung dengan cluster yang ada atau bergabung dengan objek lain membentuk cluster baru dan demikian seterusnya, dimana kedekatan jarak antar objek tetap diperhitungkan. Proses akan berlanjut hingga akhirnya terbentuk satu cluster yang terdiri dari keseluruhan objek. Metode Agglomerative terbagi menjadi beberapa jenis yaitu metode single linkage, metode complete linkage, metode average linkage, metode ward, dan metode centroid.

b. Metode Divisive (Pemecahan)

Pengelompokan metode Divisive dimulai dari satu cluster besar yang terdiri dari semua objek. Kemudian dua objek dengan jarak terjauh atau nilai ketidakmiripannya tertinggi akan dipisahkan dan membentuk cluster yang lebih kecil dan demikian seterusnya. Proses ini akan berlanjut hingga setiap objek menjadi cluster tersendiri.

\section{Metode Non-Hirarki}


Berbeda dengan metode hirarki, proses metode non-hirarki dimulai dengan menentukan jumlah cluster yang diinginkan terlebih dahulu. Setelah jumlah cluster ditentukan, maka proses pengelompokan dilakukan tanpa mengikuti proses hirarki. Metode ini biasanya disebut dengan K-means clustering.

\section{Melakukan Interpretasi terhadap Hasil Clustering}

Tahap ini dimulai dengan menganalisis variabel-variabel yang membedakan antar setiap cluster. Analisis dilakukan dengan melihat nilai signifikansi (sig.) dan nilai $F$ pada tabel ANOVA. Apabila nilai sig. $>0,05$, maka tidak ada perbedaan yang berarti antara masing-masing cluster dan jika nilai sig. $<0,05$ maka ada perbedaan yang berarti antara masing-masing cluster yang berhubungan dengan variabel tersebut. Kemudian semakin besar nilai $F$ maka semakin besar pula perbedaan antara masingmasing cluster yang berhubungan dengan variabel tersebut.

Interpretasi hasil clustering dapat dilakukan berdasarkan output final cluster centers. Jika nilai output final cluster centers berbentuk z-score maka terdapat ketentuan sebagai berikut.

1. Nilai negatif (-) artinya rata-rata variabel dalam cluster berada di bawah rata-rata populasi

2. Nilai positif $(+)$ artinya rata-rata variabel dalam cluster berada di atas rata-rata populasi

Biasanya, interpretasi hasil clustering juga dapat dilakukan berdasarkan nilai rata-rata keseluruhan variabel pada tiap cluster yang terbentuk.

\section{K-Means Clustering}

Metode K-Means pertama kali diperkenalkan oleh James MacQueen pada tahun 1976. K-Means Clustering adalah metode pengelompokan non-hirarki yang mengelompokan data/objek ke dalam cluster-cluster. K-Means Clustering merupakan metode pengelompokan yang banyak digunakan karena sederhana dan mudah diimplementasikan. K-Means Clustering digunakan sebagai alternatif metode cluster untuk data berukuran besar karena memiliki kecepatan yang lebih tinggi dibandingkan metode hirarki (Sitepu, 2011).

Tujuan dari K-Means clustering adalah mengelompokkan data/objek dengan memaksimalkan kemiripan data dalam satu cluster dan meminimalkan kemiripan data antar cluster. Ukuran kemiripan yang digunakan dalam k-means clustering adalah ukuran jarak. Adapun langkah-langkah dari algoritma $k$-means adalah sebagai berikut.

1. Menentukan banyak $k$-cluster yang ingin dibentuk.

2. Membangkitkan nilai random untuk pusat cluster (centroid) awal sebanyak $k$-cluster.

3. Menghitung jarak setiap data terhadap masing-masing centroid. Untuk menghitung jarak data ke centroid dapat menggunakan ukuran jarak seperti jarak euclidean.

4. Mengelompokan setiap data berdasarkan jarak terkecil/terdekat antara data dengan centroid.

5. Mengupdate nilai centroid. Nilai centroid baru diperoleh dari rata-rata dari data pada setiap cluster dengan menggunakan rumus di bawah.

$$
C_{i j}=\frac{1}{n_{i}} \sum_{k=1}^{n_{i}} x_{k j}
$$

$$
\begin{array}{ll}
C_{i j} & \text { Keterangan } \\
n_{i} & : \text { pusat } \text { cluster (centroid) dari cluster ke-i pada variabel ke-j } \\
x_{k j} & : \text { nilai data ke-k yang ada di dalam } \text { cluster } \text { pada variabel ke-j } \\
i, k & : \text { indeks dari } \text { cluster } \\
j & : \text { indeks dari variabel }
\end{array}
$$


6. Melakukan pengulangan dari langkah 3 sampai 5 hingga anggota tiap cluster atau centroid tidak ada yang berubah.

\section{HASIL DAN PEMBAHASAN}

\section{Data}

Data yang digunakan dalam penelitian ini diperoleh melalui bagian pusat data dan sarana informatika (PDSI) Kementerian Komunikasi dan Informatika Republik Indonesia yang berupa data persentase siswa umur 5-24 tahun yang mengakses internet selama 3 Bulan terakhir menurut Provinsi dan Jenjang Pendidikan, 2017 (Perkotaan + Perdesaan). Data-data tersebut berisi data persentase jumlah pengguna internet berpendidikan SD, SMP, SMA dan Perguruan tinggi yang akan dijadikan variabel dalam penelitian ini. Data tersebut disajikan dalam tabel berikut.

\section{Proses Analisis Cluster}

Beberapa langkah untuk mengelompokan data ke dalam beberapa cluster, yaitu sebagai berikut.

TABEL 1. Data Jumlah Persentase Pengguna Internet Berpendidikan SD, SMP, SMA, dan Perguruan Tinggi (PT) per Provinsi 2017

\begin{tabular}{|c|c|c|c|c|c|}
\hline No & Provinsi & SD & SMP & SMA & PT \\
\hline 1 & Aceh & 3,33 & 24,37 & 52,61 & 79,03 \\
\hline 2 & Sumatera Utara & 8,79 & 44,92 & 74,60 & 90,18 \\
\hline 3 & Sumatera Barat & 11,27 & 53,90 & 81,64 & 88,56 \\
\hline 4 & Riau & 10,21 & 50,70 & 75,29 & 88,74 \\
\hline 5 & Jambi & 9,00 & 47,27 & 78,36 & 89,00 \\
\hline 6 & Sumatera Selatan & 8,29 & 43,49 & 75,91 & 93,30 \\
\hline 7 & Bengkulu & 8,96 & 45,76 & 73,74 & 84,02 \\
\hline 8 & Lampung & 6,77 & 42,24 & 79,80 & 83,48 \\
\hline 9 & Kep. Bangka Belitung & 11,71 & 47,89 & 83,13 & 91,45 \\
\hline 10 & Kepulauan Riau & 18,75 & 68,86 & 88,37 & 97,92 \\
\hline 11 & DKI Jakarta & 28,74 & 76,56 & 93,03 & 99,77 \\
\hline 12 & Jawa Barat & 13,35 & 64,42 & 88,84 & 93,64 \\
\hline 13 & Jawa Tengah & 13,94 & 66,93 & 90,16 & 93,24 \\
\hline 14 & DI Yogyakarta & 25,73 & 82,66 & 95,97 & 98,68 \\
\hline 15 & Jawa Timur & 15,09 & 66,78 & 86,45 & 94,99 \\
\hline 16 & Banten & 12,52 & 55,22 & 85,40 & 94,27 \\
\hline 17 & Bali & 22,34 & 72,04 & 91,72 & 95,14 \\
\hline 18 & Nusa Tenggara Barat & 4,29 & 32,60 & 66,71 & 78,39 \\
\hline 19 & Nusa Tenggara Timur & 2,92 & 19,74 & 51,60 & 83,48 \\
\hline 20 & Kalimantan Barat & 8,06 & 39,52 & 67,74 & 86,46 \\
\hline 21 & Kalimantan Tengah & 11,73 & 48,14 & 76,19 & 76,44 \\
\hline 22 & Kalimantan Selatan & 16,23 & 61,92 & 84,43 & 90,65 \\
\hline 23 & Kalimantan Timur & 17,26 & 59,48 & 85,68 & 93,90 \\
\hline 24 & Kalimantan Utara & 11,38 & 46,06 & 85,49 & 93,45 \\
\hline 25 & Sulawesi Utara & 13,88 & 50,35 & 77,20 & 90,28 \\
\hline 26 & Sulawesi Tengah & 6,03 & 39,80 & 72,01 & 84,10 \\
\hline 27 & Sulawesi Selatan & 10,83 & 51,13 & 81,01 & 92,73 \\
\hline 28 & Sulawesi Tenggara & 5,48 & 34,76 & 71,41 & 88,43 \\
\hline
\end{tabular}




\begin{tabular}{llllll}
29 & Gorontalo & 7,63 & 45,90 & 77,49 & 90,31 \\
30 & Sulawesi Barat & 3,60 & 26,53 & 63,35 & 81,23 \\
31 & Maluku & 6,54 & 37,57 & 56,86 & 78,80 \\
32 & Maluku Utara & 3,17 & 21,85 & 39,83 & 66,09 \\
33 & Papua Barat & 6,45 & 33,61 & 62,05 & 75,91 \\
34 & Papua & 3,87 & 20,22 & 44,03 & 78,45 \\
\hline
\end{tabular}

\section{Proses Standardisasi Data}

Hal yang perlu diperhatikan dalam analisis cluster adalah satuan dari data-data penelitian, apakah memiliki keanekaragaman atau tidak. Data-data pada Tabel 1 belum memiliki satuan yang seragam. Oleh karena itu, perlu dilakukan proses standardisasi data terlebih dahulu ke bentuk z-score. Untuk mengetahui nilai rata-rata dan simpangan baku, dapat dilihat dari tampilan output SPSS berikut.

TABEL 2. Descriptive Statistics

\begin{tabular}{cccccc}
\hline & N & Minimum & Maximum & Mean & Std. Deviation \\
\hline SD & 34 & 2,92 & 28,74 & 10,8276 & 6,32304 \\
SMP & 34 & 19,74 & 82,66 & 47,7409 & 16,20069 \\
SMA & 34 & 39,83 & 95,97 & 75,2382 & 13,93851 \\
PT & 34 & 66,09 & 99,77 & 87,7797 & 7,64283 \\
Valid N (listwise) & 34 & & & & \\
\hline
\end{tabular}

Dengan menggunakan rumus persamaan (1), diperoleh nilai standardisasi dari masing-masing data adalah sebagai berikut.

- Untuk data ke-1 (Aceh)

$$
\begin{aligned}
& Z_{S D}=\frac{3,33-10,8276}{6,32304}=-1,185758749 \approx-1,18577 \\
& Z_{S M P}=\frac{24,37-47,7409}{16,20069}=-1,442586705 \approx-1,44259 \\
& Z_{S M A}=\frac{52,61-75,2382}{13,93851}=-1,623430338 \approx-1,62343 \\
& Z_{P T}=\frac{79,03-87,7797}{7,64283}=-1,144824626 \approx-1,14482
\end{aligned}
$$

Perhitungan nilai standardisasi data selanjutnya dilakukan dengan cara yang sama seperti di atas. Hasil nilai standardisasi semua data dapat dilihat dari tampilan "Data View" program SPSS berikut.

TABEL 3. Nilai Z-Score SD, SMP, SMA, dan Perguruan Tinggi (PT)

\begin{tabular}{clcccc}
\hline No & \multicolumn{1}{c}{ Provinsi } & Zsd & Zsmp & Zsma & Zpt \\
\hline 1 & Aceh & $-1,18577$ & $-1,44259$ & $-1,62343$ & $-1,14482$ \\
2 & Sumatera Utara & $-0,32226$ & $-0,17412$ & $-0,04579$ & 0,31406 \\
3 & Sumatera Barat & 0,06996 & 0,38018 & 0,45929 & 0,10209 \\
4 & Riau & $-0,09768$ & 0,18265 & 0,00371 & 0,12565 \\
5 & Jambi & $-0,28905$ & $-0,02907$ & 0,22397 & 0,15967 \\
6 & Sumatera Selatan & $-0,40133$ & $-0,26239$ & 0,04819 & 0,72228 \\
7 & Bengkulu & $-0,29537$ & $-0,12227$ & $-0,10749$ & $-0,49193$ \\
8 & Lampung & $-0,64172$ & $-0,33955$ & 0,32728 & $-0,56258$ \\
9 & Kep. Bangka Belitung & 0,13955 & 0,0092 & 0,56618 & 0,48023 \\
10 & Kepulauan Riau & 1,25293 & 1,30359 & 0,94212 & 1,32677
\end{tabular}




\begin{tabular}{|c|c|c|c|c|c|}
\hline 11 & DKI Jakarta & 2,83287 & 1,77888 & 1,27645 & 1,56883 \\
\hline 12 & Jawa Barat & 0,39891 & 1,02953 & 0,97584 & 0,76677 \\
\hline 13 & Jawa Tengah & 0,49222 & 1,18446 & 1,07054 & 0,71443 \\
\hline 14 & DI Yogyakarta & 2,35683 & 2,15541 & 1,48737 & 1,42621 \\
\hline 15 & Jawa Timur & 0,6741 & 1,1752 & 0,80437 & 0,94341 \\
\hline 16 & Banten & 0,26765 & 0,46165 & 0,72904 & 0,8492 \\
\hline 17 & Bali & 1,8207 & 1,49988 & 1,18246 & 0,96303 \\
\hline 18 & Nusa Tenggara Barat & $-1,03394$ & $-0,93458$ & $-0,61185$ & $-1,22856$ \\
\hline 19 & Nusa Tenggara Timur & $-1,25061$ & $-1,72838$ & $-1,69589$ & $-0,56258$ \\
\hline 20 & Kalimantan Barat & $-0,43771$ & $-0,50744$ & $-0,53795$ & $-0,17267$ \\
\hline 21 & Kalimantan Tengah & 0,14271 & 0,02464 & 0,06828 & $-1,4837$ \\
\hline 22 & Kalimantan Selatan & 0,85439 & 0,87522 & 0,65945 & 0,37555 \\
\hline 23 & Kalimantan Timur & 1,01729 & 0,72461 & 0,74913 & 0,80079 \\
\hline 24 & Kalimantan Utara & 0,08736 & $-0,10375$ & 0,7355 & 0,74191 \\
\hline 25 & Sulawesi Utara & 0,48273 & 0,16105 & 0,14074 & 0,32714 \\
\hline 26 & Sulawesi Tengah & $-0,75876$ & $-0,49016$ & $-0,23161$ & $-0,48146$ \\
\hline 27 & Sulawesi Selatan & 0,00037 & 0,2092 & 0,41409 & 0,6477 \\
\hline 28 & Sulawesi Tenggara & $-0,84574$ & $-0,80125$ & $-0,27465$ & 0,08509 \\
\hline 29 & Gorontalo & $-0,50571$ & $-0,11363$ & 0,16155 & 0,33107 \\
\hline 30 & Sulawesi Barat & $-1,14306$ & $-1,30926$ & $-0,85291$ & $-0,85697$ \\
\hline 31 & Maluku & $-0,6781$ & $-0,62781$ & $-1,31852$ & $-1,17492$ \\
\hline 32 & Maluku Utara & $-1,21107$ & $-1,59813$ & $-2,54032$ & $-2,83791$ \\
\hline 33 & Papua Barat & $-0,69233$ & $-0,87224$ & $-0,94617$ & $-1,55305$ \\
\hline 34 & Papua & $-1,10036$ & $-1,69875$ & $-2,23899$ & $-1,22071$ \\
\hline
\end{tabular}

Untuk proses analisis cluster selanjutnya, data yang akan digunakan adalah data nilai z-score pada tabel di atas.

\section{Menentukan Ukuran Kemiripan}

Ukuran kemiripan yang akan digunakan dalam proses clustering adalah ukuran jarak. Semakin kecil jarak antara dua objek, maka semakin tinggi tingkat kemiripannya. Dalam penelitian ini mengukur jarak antar dua objek dihitung dengan menggunakan jarak euclidean pada persamaan (2). Jarak euclidean merupakan jarak suatu garis lurus antara dua titik yang menghubungkan antar objek berupa akar jumlah kuadrat perbedaan nilai untuk tiap variabel.

\section{Proses Clustering}

Pada penelitian ini, metode clustering yang akan digunakan adalah metode $K$-means clustering. Metode ini dimulai dengan menentukan jumlah cluster yang ingin dibentuk. Setelah jumlah cluster diketahui, barulah proses clustering dilakukan. Proses clustering dengan metode k-means pada penelitian ini dilakukan dengan bantuan program SPSS 25. Berikut merupakan tampilan output program SPSS.

TABEL 4. Initial Cluster Centers

\begin{tabular}{lccc}
\hline \multirow{2}{*}{ Zscore } & \multicolumn{3}{c}{ Cluster } \\
\cline { 2 - 4 } & $\mathbf{1}$ & $\mathbf{2}$ & $\mathbf{3}$ \\
\hline SD & $-1,21107$ & 2,83287 &, 08736 \\
\hline SMP & $-1,59813$ & 1,77888 &,- 10375 \\
\hline
\end{tabular}




\begin{tabular}{llll}
\hline SMA & $-2,54032$ & 1,27645 &, 73550 \\
\hline $\begin{array}{l}\text { Perguruan } \\
\text { Tinggi }\end{array}$ & $-2,83791$ & 1,56883 &, 74191 \\
\hline
\end{tabular}

Tabel 4 di atas merupakan tampilan awal proses clustering sebelum dilakukan iterasi. Tabel tersebut menunjukkan tiga buah cluster yang pertama kali terbentuk dengan nilai pusat cluster (centroid)-nya masing-masing. Kemudian metode K-Means Clustering akan melakukan proses iterasi atau realokasi cluster yang ada, yang memuat perubahan pada nilai pusat cluster (centroid). Proses iterasi berhenti jika centroid atau anggota tiap cluster tidak berubah. Untuk mengetahui berapa kali proses iterasi dilakukan, dapat dilihat dari tampilan output program SPSS berikut.

TABEL 5. Iteration History

\begin{tabular}{cccc}
\hline \multirow{2}{*}{ Iteration } & \multicolumn{3}{c}{ Change in Cluster Center } \\
\cline { 2 - 4 } & $\mathbf{1}$ & $\mathbf{2}$ & $\mathbf{3}$ \\
\hline $\mathbf{1}$ & 1,886 &, 813 &, 710 \\
$\mathbf{2}$ &, 000 &, 000 &, 000 \\
\hline a. Convergence achieved due to no or \\
small change in cluster centers. The maximum \\
absolute coordinate change for any center is \\
,000. The current iteration is 2. The minimum \\
distance between initial centers is \\
3,473.
\end{tabular}

Berdasarkan tabel 5 dapat diketahui bahwa proses iterasi untuk mengelompokan 34 objek dilakukan sebanyak 2 kali dan jarak minimum antar pusat cluster (centroid) awal yaitu 3,473. Adapun tabel pusat cluster (centroid) akhir dari masing-masing cluster setelah iterasi berhenti dapat dilihat dari tampilan output program SPSS berikut.

TABEL 6. Final Cluster Centers

\begin{tabular}{cccc}
\hline \multirow{2}{*}{ Z-score } & \multicolumn{3}{c}{ Cluster } \\
\cline { 2 - 4 } & $\mathbf{1}$ & $\mathbf{2}$ & $\mathbf{3}$ \\
\hline SD & $-1,03691$ & 2,06583 &, 00145 \\
SMP & $-1,27647$ & 1,68444 &, 15791 \\
SMA & $-1,47851$ & 1,22210 &, 31544 \\
PT & $-1,32244$ & 1,32121 &, 24067 \\
\hline
\end{tabular}

Tabel 6 di atas merupakan rata-rata dari data z-score setiap cluster yang akan digunakan untuk proses interpretasi terhadap hasil clustering. Selanjutnya dapat diketahui jumlah anggota dari setiap cluster yang terbentuk melalui tampilan program SPSS berikut.

TABEL 7. Number of Cases in each Cluster

\begin{tabular}{ccccr}
\hline \multicolumn{3}{c}{ Cluster } & \multirow{2}{*}{ Valid } & \multirow{2}{*}{ Missing } \\
\hline 1 & 2 & 3 & &, 000 \\
\hline 8,000 & 4,000 & 22,000 & 34,000 &, \\
\hline
\end{tabular}

Berdasarkan tabel 7 di atas menunjukan bahwa cluster 1 mempunyai 8 anggota, cluster 2 mempunyai 4 anggota dan cluster 3 mempunyai 22 anggota. Selanjutnya untuk mengetahui provinsiprovinsi mana saja yang masuk ke dalam cluster 1, 2 dan 3 dapat dilihat pada tabel 8 .

TABEL 8. Tampilan "Data View" program SPSS

\begin{tabular}{clcccccc}
\hline No & Provinsi & QCL_1 & QCL_2 & No & Provinsi & QCL_1 & QCL_2 \\
\hline 1 & Aceh & 1 & 0,31985 & 18 & Nusa Tenggara Barat & 1 & 0,93638 \\
2 & Sumatera Utara & 3 & 0,59237 & 19 & Nusa Tenggara Timur & 1 & 0,93517 \\
3 & Sumatera Barat & 3 & 0,30658 & 20 & Kalimantan Barat & 3 & 1,23882 \\
4 & Riau & 3 & 0,34762 & 21 & Kalimantan Tengah & 3 & 1,75279 \\
\hline
\end{tabular}




\begin{tabular}{clccclcc}
5 & Jambi & 3 & 0,36644 & 22 & Kalimantan Selatan & 3 & 1,17413 \\
6 & Sumatera Selatan & 3 & 0,80141 & 23 & Kalimantan Timur & 3 & 1,36195 \\
7 & Bengkulu & 3 & 0,93924 & 24 & Kalimantan Utara & 3 & 0,70961 \\
8 & Lampung & 3 & 1,14301 & 25 & Sulawesi Utara & 3 & 0,51927 \\
9 & Kep. Bangka Belitung & 3 & 0,4018 & 26 & Sulawesi Tengah & 3 & 1,34856 \\
10 & Kepulauan Riau & 2 & 0,94036 & 27 & Sulawesi Selatan & 3 & 0,42195 \\
11 & DKI Jakarta & 2 & 0,81335 & 28 & Sulawesi Tenggara & 3 & 1,41779 \\
12 & Jawa Barat & 3 & 1,27696 & 29 & Gorontalo & 3 & 0,60233 \\
13 & Jawa Tengah & 3 & 1,44544 & 30 & Sulawesi Barat & 1 & 0,78765 \\
14 & DI Yogyakarta & 2 & 0,6228 & 31 & Maluku & 1 & 0,77257 \\
15 & Jawa Timur & 3 & 1,49005 & 32 & Maluku Utara & 1 & 1,88624 \\
16 & Banten & 3 & 0,83935 & 33 & Papua Barat & 1 & 0,78657 \\
17 & Bali & 2 & 0,4733 & 34 & Papua & 1 & 0,87808 \\
\hline
\end{tabular}

Pada tabel di atas kolom $\mathrm{QCL}_{1}$ menunjukan omor cluster dari setiap provinsi dan $\mathrm{QCL}_{2}$ menunjukan jarak antar objek dengan centroid. Maka telah diperoleh hasil clustering dengan metode $k$-means clustering sebagai berikut.

\begin{tabular}{|c|c|c|}
\hline Cluster 1 & Cluster 2 & Cluster 3 \\
\hline Aceh & Kepulauan Riau & Sumatra Utara \\
\hline Nusa Tenggara Barat & DKI Jakarta & Sumatra Barat \\
\hline Nusa Tenggara Timur & DI Yogyakarta & Riau \\
\hline Sulawesi Barat & Bali & Jambi \\
\hline Maluku & & Sumatra Selatan \\
\hline Maluku Utara & & Bengkulu \\
\hline Papua Barat & & Lampung \\
\hline \multirow[t]{15}{*}{ Papua } & & Kep. Bangka Belitung \\
\hline & & Jawa Barat \\
\hline & & Jawa Tengah \\
\hline & & Jawa Timur \\
\hline & & Banten \\
\hline & & Kalimantan Barat \\
\hline & & Kalimantan Tengah \\
\hline & & Kalimantan Timur \\
\hline & & Kalimantan Selatan \\
\hline & & Kalimantan Utara \\
\hline & & Sulawesi Utara \\
\hline & & Sulawesi Tengah \\
\hline & & Sulawesi Selatan \\
\hline & & Sulawesi Tenggara \\
\hline & & Gorontalo \\
\hline 8 anggota & 4 anggota & 22 anggota \\
\hline
\end{tabular}

Berdasarkan tabel 9 di atas dapat diketahui bahwa Cluster 1 terdiri dari 8 anggota yaitu Aceh, Nusa Tenggara Barat, Nusa Tenggara Timur, Sulawesi Barat, Maluku, Maluku Utara, Papua Barat, dan Papua. Sedangkan Cluster 2 terdiri dari 4 anggota yaitu Kepulauan Riau, DKI Jakarta, DI Yogyakarta, dan Bali. Sedangkan Cluster 3 terdiri dari 22 anggota yaitu Sumatera Utara, Sumatera Barat, Riau, Jambi, Sumatera Selatan, Bengkulu, Lampung, Kep. Bangka Belitung, Jawa Barat, Jawa Tengah, Jawa Timur, Banten, Kalimantan Barat, Kalimantan Tengah, Kalimantan Selatan, Kalimantan Timur, Kalimantan Utara, Sulawesi Utara, Sulawesi Tengah, Sulawesi Selatan, Sulawesi Tenggara, dan Gorontalo. 


\section{Interpretasi Hasil Clustering}

Dalam proses clustering setelah cluster terbentuk dan diketahui masing-masing anggotanya, tahap berikutnya yaitu melakukan interpretasi terhadap hasil clustering. Tahap ini dimulai dengan menganalisis variabel-variabel yang membedakan antara tiga cluster. Analisis dilakukan dengan melihat nilai signifikansi (sig.) dan nilai $F$ pada tabel ANOVA. Nilai signifikansi (sig.) dan nilai $F$ dari masing-masing variabel dapat dilihat dari tampilan output program SPSS berikut.

TABEL 10. ANOVA

\begin{tabular}{ccccccc}
\hline \multirow{2}{*}{ Z-score } & $\begin{array}{c}\text { Cluster } \\
\text { Mean Square }\end{array}$ & $\boldsymbol{d f}$ & Mean Square & $\boldsymbol{d}$ f & $\boldsymbol{F}$ & Sig. \\
\hline SD & 12,836 & 2 &, 236 & 31 & 54,302 &, 000 \\
SMP & 12,466 & 2 &, 260 & 31 & 47,905 &, 000 \\
SMA & 12,826 & 2 &, 237 & 31 & 54,103 &, 000 \\
PT & 11,124 & 2 &, 347 & 31 & 32,070 &, 000 \\
\hline \multicolumn{7}{c}{ The F tests should be used only for descriptive purposes because the } \\
clusters have been chosen to maximize the differences \\
among cases in different clusters. The observed \\
significance levels are not corrected for this and thus \\
cannot be interpreted as tests of the hypothesis that \\
the cluster means are equal.
\end{tabular}

Berdarkan tabel 10 di atas dapat diketahui bahwa nilai sig. untuk semua variabel lebih kecil dari 0,05 . Hal ini menunjukkan bahwa ada perbedaan yang berarti antara cluster 1 , cluster 2 , dan cluster 3 , yang berhubungan dengan semua variabel tersebut. Kemudian nilai $F$ terbesar adalah 54,302 yang dimiliki variabel SD. Hal ini menunjukkan bahwa ada perbedaan yang berarti antara provinsi-provinsi pada ketiga cluster yang berhubungan dengan jumlah pengguna internet yang berpendidikan SD.

Selanjutnya akan dianalisis persentase jumlah pengguna internet masing-masing provinsi yang dikelompokan ke dalam masing-masing cluster yang dapat dilihat dari tabel nilai pusat cluster (centroid) akhir seperti di bawah ini.

TABEL 11. Final Cluster Centers

\begin{tabular}{cccc}
\hline \multirow{2}{*}{ Z-score } & \multicolumn{3}{c}{ Cluster } \\
\cline { 2 - 4 } & $\mathbf{1}$ & $\mathbf{2}$ & $\mathbf{3}$ \\
\hline SD & $-1,03691$ & 2,06583 &, 00145 \\
SMP & $-1,27647$ & 1,68444 &, 15791 \\
SMA & $-1,47851$ & 1,22210 &, 31544 \\
PT & $-1,32244$ & 1,32121 &, 24067 \\
\hline
\end{tabular}

Berdasarkan tabel 11 di atas, setiap cluster dapat didefinisikan sebagai berikut.

1. Cluster 1

Dalam Cluster 1 berisi provinsi-provinsi yang mempunyai persentase jumlah pengguna internet berpendidikan SD, SMP, SMA dan Perguruan Tinggi (PT) di bawah rata-rata populasi provinsi yang diteliti. Hal ini dapat dilihat dari nilai negatif (-) pada seluruh variabel Cluster 1 yang terdapat pada tabel Final Cluster Centers.

2. Cluster 2

Dalam Cluster 2 berisi provinsi-provinsi yang mempunyai persentase jumlah pengguna internet berpendidikan SD, SMP, SMA dan Perguruan Tinggi (PT) di atas rata-rata populasi provinsi yang diteliti. Hal ini dapat dilihat dari nilai positif (+) pada seluruh variabel Cluster 2 yang terdapat pada tabel Final Cluster Centers.

3. Cluster 3

Dalam Cluster 3 berisi provinsi-provinsi yang mempunyai persentase jumlah pengguna internet berpendidikan SD, SMP, SMA dan Perguruan Tinggi (PT) di atas rata-rata populasi provinsi yang diteliti. Hal ini dapat dilihat dari nilai positif (+) pada seluruh variabel Cluster 3 yang terdapat pada tabel Final Cluster Centers. 
Untuk mengetahui provinsi-provinsi dengan persentase pengguna internet yang tinggi, sedang atau rendah dapat dilihat dari rata-rata keseluruhan variabel pada tiap cluster yang terbentuk. Berikut merupakan rata- rata keseluruhan variabel pada tiap cluster.

TABEL 12. Rata-rata Persentase Jumlah Pengguna Internet

\begin{tabular}{lr}
\hline & Rata - Rata \\
\hline Cluster 1 & 40,91 \\
Cluster 2 & 72,27 \\
Cluster 3 & 57,60 \\
\hline
\end{tabular}

Berdasarkan tabel di atas dapat dilihat bahwa dalam mengelompokan provinsi ke dalam masingmasing cluster dengan metode $K$-Means clustering dapat ditarik kesimpulan sebagai berikut.

1. Cluster 1

Cluster 1 mempunyai rata-rata persentase jumlah pengguna internet menurut jenjang pendidikan terendah yaitu sebesar 40,91. Artinya pada tahun 2017 provinsi pada cluster 1 menjadi provinsi dengan persentase jumlah pengguna internet menurut jenjang pendidikannya rendah. Dapat dikatakan provinsi pada cluster 1 merupakan daerah yang memiliki infrastruktur kurang baik untuk mendukung penggunaan internet.

2. Cluster 2

Cluster 2 mempunyai rata-rata persentase jumlah pengguna internet menurut jenjang pendidikan tertinggi yaitu sebesar 72,27. Artinya pada tahun 2017 provinsi pada cluster 2 menjadi provinsi dengan persentase jumlah pengguna internet menurut jenjang pendidikannya tinggi. Dapat dikatakan provinsi pada cluster 2 merupakan daerah yang memiliki infrastruktur baik untuk mendukung penggunaan internet.

3. Cluster 3

Cluster 3 mempunyai rata-rata persentase jumlah pengguna internet menurut jenjang pendidikan cukup tinggi yaitu sebesar 57,60. Artinya pada tahun 2017 provinsi pada cluster 3 menjadi provinsi dengan persentase jumlah pengguna internet menurut jenjang pendidikannya sedang. Dapat dikatakan provinsi pada cluster 3 merupakan daerah yang memiliki infrastruktur cukup baik untuk mendukung penggunaan internet.

Dari uraian di atas, dapat diketahui bahwa urutan cluster provinsi dengan persentase jumlah pengguna internet menurut jenjang pendidikan tertinggi sampai terendah yaitu cluster 2 , cluster 3 , dan cluster 1.

\section{KESIMPULAN DAN SARAN}

\section{Kesimpulan}

Hasil pengelompokan provinsi di Indonesia berdasarkan data persentase siswa yang mengakses internet menurut jenjang pendidikan menggunakan metode $k$-means terbentuk mejadi 3 cluster. Cluster 1 terdiri dari 8 provinsi, Cluster 2 terdiri dari 4 provinsi, dan Cluster 3 terdiri dari 22 provinsi.

Interpretasi dari hasil clustering menunjukan bahwa provinsi pada cluster 1 merupakan daerah yang memiliki infrastruktur kurang baik untuk mendukung penggunaan internet karena mempunyai rata-rata persentase jumlah pengguna internet menurut jenjang pendidikan terendah yaitu sebesar 40,91, sementara provinsi pada cluster 2 merupakan daerah yang memiliki infrastruktur baik untuk mendukung penggunaan internet karena mempunyai rata-rata persentase jumlah pengguna internet menurut jenjang pendidikan tertinggi yaitu sebesar 72,27, dan provinsi pada cluster 3 merupakan daerah yang memiliki infrastruktur cukup baik untuk mendukung penggunaan internet karena mempunyai rata-rata persentase jumlah pengguna internet menurut jenjang pendidikan cukup tinggi yaitu sebesar 57,60. Oleh karena itu, perlu adanya pemerataan infrastruktur yang mendukung penggunaan internet pada masyarakat Indonesia. 


\section{Saran}

Perlu dilakukan penelitian lanjutan dengan menggunakan metode clustering lainnya, kemudian dilakukan perbandingan yang pada akhirnya dapat diketahui metode terbaik untuk clustering. Selanjutnya dibangun perhitungannya dengan menggunakan aplikasi software tertentu, sehingga prosesnya menjadi lebih cepat, akurat, dan applicable.

\section{UCAPAN TERIMA KASIH}

Terima kasih kepada Bapak Dr. Ir. Bagus Sumargo, M.Si. selaku dosen pembimbing yang telah membimbing, mengarahkan, serta memberikan dorongan untuk menyelesaikan penelitian ini. Selain itu, terima kasih kepada seluruh staf PDSI Kementrian Komunikasi dan Informatika atas saran dan ketersediaan data dalam menunjang penelitian ini.

\section{REFERENSI}

Abdurrahman, Ginanjar (2016) 'Clustering Data Ujian Tengah Semester (UTS) Data Mining Menggunakan Algoritma K-Means’, Jurnal Sistem \& Teknologi Informasi Indonesia, 1(2).

Arai, K., Barakbah, A. R. (2007) 'Hierarchical K-Means: an algorithm for centroids initialization for K-Means'. The Faculty of Science and Engineering, Saga University, 36(1).

Panji, Aditya (2014) 'Hasil Survei Pemakaian Internet Remaja Indonesia' [online]. Available at: https://tekno.kompas.com/read/2014/02/19/1623250/Hasil.Survei.Pemakaian.Internet.Remaja.Indo nesia (Accessed: 5 September 2018).

Rivani, Edmira (2010) 'Aplikasi K-means Cluster untuk Pengelompokan Provinsi berdasarkan Produksi Padi, Jagung, Kedelai, dan Kacang Hijau Tahun 2009’, Jurnal Mat Stat, 10(2), pp.122134.

Sitepu, Robinson, dkk. (2011) 'Analisis Cluster terhadap Tingkat Pencemaran Udara pada Sektor Industri di Sumatera Selatan', Jurnal Penelitian Sains, 14(3A), 14303.

Zakaria, Muhammad (2018) 'Pengertian Internet Beserta Fungsi dan Manfaat Internet yang Perlu Anda Ketahui' [online]. Available at: https://www.nesabamedia.com/pengertian-fungsi-danmanfaat-internet-lengkap/ (Accessed: 5 September 2018). 